\title{
Vestibular Ganglion
}

National Cancer Institute

\section{Source}

National Cancer Institute. Vestibular Ganglion. NCI Thesaurus. Code C33870.

The collection of afferent neurons that serve to connect the hair cells of the vestibular sensory end organs with the brain. 